\title{
PEMBERDAYAAN KADER MELALUI PELATIHAN PENCEGAHAN DAN PENANGGULANGAN PENYAKIT GIGI DI SURABAYA
}

\section{EMPOWERMENT OF CADRES THROUGH TRAINING ON PREVENTION AND MANAGEMENT OF DENTAL DISEASES IN SURABAYA}

\author{
Titiek Berniyanti*1 $^{1}$, Retno Palupi ${ }^{1}$, Adriani Sari Fadilah ${ }^{2}$, Nabilah Khansa Salsabila ${ }^{2}$ \\ ${ }^{1}$.Department of Dental Public Health, Faculty of Dental Medicine, Universitas Airlangga, Indonesia. \\ ${ }^{2}$ Undergraduate Student, Faculty of Dental Medicine, Universitas Airlangga Indonesia. \\ Email: titiek-b@fkg.unair.ac.id
}

\begin{abstract}
Abstrak
Diketahui bahwa perilaku ibu dan anak memiliki hubungan yang signifikan dengan kejadian karies. Kesehatan mulut dan gigi merupakan sesuatu yang sangat penting bagi setiap individu di berbagai skala usia, termasuk anak-anak. Artikel ini bertujuan untuk mengetahui perilaku ibu tentang kesehatan gigi rongga mulut ditinjau dari predisposisi, pendorong, dan penguat sebagai faktor risiko keparahan karies gigi pada anak usia 4-6 tahun di Surabaya. Metode: Pelatihan dan Pemberdayaan kader / ibu tentang pencegahan dan penanggulangan penyakit gigi (Cegatan Pagi / Cegah dan Tangani Penyakit Gigi), dan edukasi melalui Game Edukasi Ular Tangga tentang Kesehatan Mulut dan Gigi Anak (Beruang Imut / Bermain). Ular Tangga Kesehatan Gigi Dan Mulut). Kesulitan ibu dalam mendidik anaknya tentang kesehatan gigi dan mulut dapat diatasi melalui permainan edukatif. Permainan ular tangga ini diharapkan dapat meningkatkan pemahaman dan minat anak dalam menjaga kesehatan mulut. Kesulitan ibu dalam mendidik anaknya tentang kesehatan gigi dan mulut dapat diatasi melalui permainan edukasi. Hasil Utama: Nilai korelasi antara 2 variabel tersebut adalah -7,242 yang berarti hubungan tersebut kuat dan positif dengan tingkat signifikan 0,000. Nilai rata-rata sebesar $-3,750$ bertanda negatif, artinya nilai tersebut cenderung meningkat setelah diberikan perlakuan. Artinya negatif artinya ada kecenderungan skor meningkat setelah perawatan. Kesimpulan: Ada peningkatan tingkat pengetahuan tentang kesehatan gigi dan mulut pada responden kader ibu wali dan guru Taman Kanak-kanak.
\end{abstract}

Kata kunci: deft, Keparahan karies Gigi, Pencegahan Penyakit Mulut, Perilaku Ibu

\begin{abstract}
It is known that the behavior of mothers and children has a significant relationship to the incidence of caries. Oral and dental health is something that is very important for every individual at various age scales, including children. This article aims to determine Mothers behavior regarding oral dental health in terms of predisposing, enabling, and reinforcing as A Risk Factor of Dental Caries Severity Of 4-6 Years Children in Surabaya. Methods: Training and Empowerment of cadres/mothers about the prevention and management of dental disease (Cegatan Pagi/Cegah dan Tangani Penyakit Gigi) and providing education through the Snake and Ladder Educational Game on Children's Oral and Dental Health or (Beruang Imut/Bermain Ular Tangga Kesehatan Gigi Dan Mulut). Difficulties for mothers in teaching their children about oral and dental health can be overcome through educational games. It is hoped that the snakes and ladders game will be able to increase children's understanding and interest in maintaining oral health Difficulties for mothers in teaching their children about oral and dental health can be overcome through educational games. Main Result: The correlation value between the 2 variables is $-7,242$, which means that the relationship is strong and positive with a significant level of 0.000 . The mean value of $-3,750$ is negative, it means that the score tends to increase after being given treatment. The mean is negative, it means the tendency of the score to increase after treatment Conclusion: There was an increase in the level of knowledge about dental and oral health among the respondents of the cadres of mother guardians and teachers of kindergarten.
\end{abstract}

Keywords: Dental Carries Severity, def-mother's Behavior, Oral Health Prevention 


\section{Introduction}

Dental caries in Indonesia is one of the top 10 diseases that many people and children complain about (Riskesdas 2018). It is the result of an imbalance in the remineralization process and demineralization. It due to the production of acid from the fermentation process and the accumulation of food waste on the tooth surface which depends on the $\mathrm{pH}$ of the saliva (Pitts 2017 and Ahmed 2015. The main factors causing caries are the host, agent, environment, and time. Ignoring the oral health conditions of children can lead to many dental problems.

Based on Basic Health Research Data (Riskesdas 2018), it was found that the prevalence of caries in the Indonesian population was $88.8 \%$, as much as $81.5 \%$ in children aged 3-4 years and $92.6 \%$ in children aged 5-9 years. The index of cavities, missing and filled teeth (dmf-T) in Indonesia in 2018 was 7 (Riskesdas 2018). The average dmf-T index of primary teeth in children aged 3-4 years is 6.2, while at 5 years is 8.1 (Riskesdas, 2018). ${ }^{4}$ According to data from the Surabaya City Health Office (Indry 2013), it is known that the number of children who need dental care increased from 2011 to 402,098 children who needed dental care, while in 2012 there were 554,917 children, meaning that the number of children who needed treatment increased by 152,819 people (I Komang Evan Wijaksana 2020) .Tooth decay can affect the child's weight, growth and quality of life because the function of chewing teeth will be disturbed, the gums are swollen and the child will also have difficulty carrying out daily activities.

The results of preliminary research on 30 samples of mothers and children aged 4-6 years with clinical examinations, interviews, and questionnaires showed that the level of maternal knowledge about oral dental health was in the low category and showed a rate of $90 \%$. the dmf-T mean index was found to be 7.83 . The attitudes of mothers regarding oral dental health were also in the poor category with a prevalence of $96.7 \%$ and a moderate category of $3.3 \%$. At kindergarten age, children generally are not able to maintain the health of their oral cavity, so parents are responsible for educating them properly. Entering school age children have a high risk of caries, because at school age children usually like to snack on food and drink according to their wishes (Halim MP. 2012). Dental caries in children occurs a lot but does not get attention from parents on the assumption that children's teeth will be replaced by permanent teeth (Indry 2013).

Preschool children are children aged 4-6 years who have maturity in various motor functions and have developed intellectually and societally. According to some experts, a child at the age of 4 years is the most optimal period to develop the potential that exists in each child. The problem that often occurs in pre-school children, especially children aged 4 years is the behavior of consuming sweet foods or drinks, but not accompanied by cleaning teeth which can cause dental caries (Wang D 2018). Around 60-90\% of preschool children have cavities which often causes pain and discomfort (WHO, 2012).

At this age, children often neglect their health, especially dental health. Tooth decay, such as caries, malocussion, dental plaque, tartar, can affect the health of other body parts, even if the child's teeth hurt, the child's appetite may decrease, this should be noticed from an early age by parents. As role models, controllers, and motivators for parents to have an important role for their children's dental health, if they don't pay attention to them, the child's dental health will develop into a problem that can interfere with the child's future. ${ }^{10}$

Based on the results of preliminary research which shows that the size of the oral health of the mother is in the poor category with a prevalence of more than $50 \%$, the researchers want to empower mothers and children. In the concept of empowerment, there are three components, including, increasing knowledge so that the community is empowered, enabling setting, namely strengthening the situation at the local level to be good, so that local people can be creative, forcing people to do something that is energized. Empowering local 
community means that, after the local setting is prepared, the local community must improve their knowledge and skills, so that they are able to make good use of the setting. This is done, among others, through education, training, and various other forms of human resource development. Socio-political support in the form of social support, political support, networking, and so on.

\section{METHOD OF COMMUNITY DEVELOPMENT}

Development in the health sector is an investment, increasing the willingness and ability to live a healthy life for everyone to achieve an optimal level of public health. Increase the ability or capacity of the community in utilizing the resources they have, both human resources (HR) and natural resources (SDA) in their environment to improve their welfare. The community in this case needs to be empowered, but the efforts made are not only limited to increasing the ability or capacity of the community to meet their daily needs, but also to build a spirit of community independence so that it develops and has a strong motivation to participate in the empowerment process. The community in this case becomes the actor or center of the empowerment

\section{Program Planning}

This empowerment activity is a continuation of the results of epidemiological research conducted in the Surabaya health center area. The maturation of activity concepts includes observing problems, identifying problems, planning activity schedules, and making the media needed for the program: Training and Empowerment of cadres/mothers about the prevention and management of dental disease or (Cegah dan Tangani Penyakit Gigi /Cegatan Pagi), and providing education through the Snake and Ladder Educational Game on Children's Oral and Dental Health or (Bermain Ular Tangga Kesehatan Gigi Dan Mulut /Beruang Imut). Difficulties for mothers in teaching their children about oral and dental health can be overcome through educational games. It is hoped that the snakes and ladders game will be able to increase children's understanding and interest in maintaining oral health Difficulties for mothers in teaching their children about oral and dental health can be overcome through educational games.

Media or props are tools used by educators to help and explain something in the educational or teaching process. Useful media generate target interest, stimulate targets to forward messages to others, and facilitate the delivery of information. Children are easily bored so that to encourage children to learn, usually teachers and parents tend to use various teaching aids and games to provoke children's interest in learning. For effective learning, it is not enough just to provide information, but it is necessary to give these students experience (Bankole 2011). According to research conducted by Hamdalah, the snake and ladder game media is more effective in increasing knowledge and attitudes towards oral health and the practice of brushing teeth. properly and correctly. The increase in knowledge, attitudes, and practices towards oral health was higher in the group that received counseling with the snake and ladder game media than the pictorial story media group.

\section{Evaluation}

The pre-test was carried out before the cadres received the material while the post-test was carried out after the cadres get the material. The pre-test and post-test were used to measure the differences in knowledge that the cadres had before and after obtaining the material with pre-test and post-test questions which included material on dental caries in children aged 4-6 years. 
The monitoring form is used for evaluation of training on the delivery of information and knowledge. The points covered in the assessment of the monitoring form contain points that must be conveyed to mothers who have children aged 4-6 years with dental caries.

In the second program, evaluation was carried out using pre-test and post-test. The pretest is carried out before the game starts, while the post-test is carried out after the game is over. Pre-test and post-test were used to measure the difference in information between mothers who had children aged 4-6 years with dental caries and children aged 4-6 years with dental caries regarding dental and oral health.

\section{RESULT AND DISCUSION}

\section{Result}

The results of the epidemiological study, of the 131 children aged 4-6 years who visited the Surabaya Health Center, only 4 (3\%) of the 131 children aged 4-6 years had a def-t 0 which was included in the very low category according to WHO. The results of the overall examination of 131 children aged 4-6 years showed that the mean def-t was 9 which was included in the very high category according to WHO.

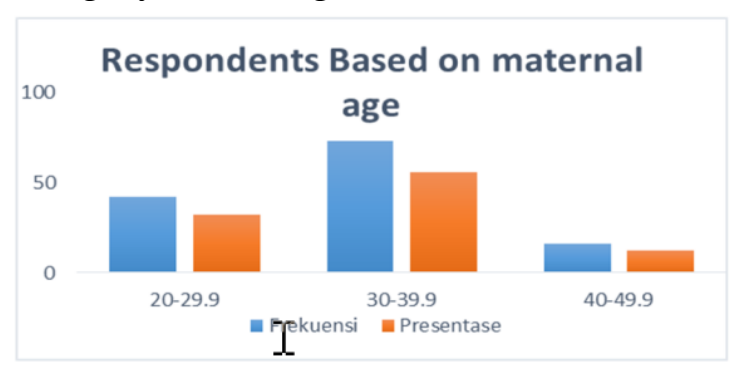

Figure 1 shows the number of respondents based on maternal age. The highest value is between the ages of 30-30.9 years. Ages 40-49.9 are in the lowest number.

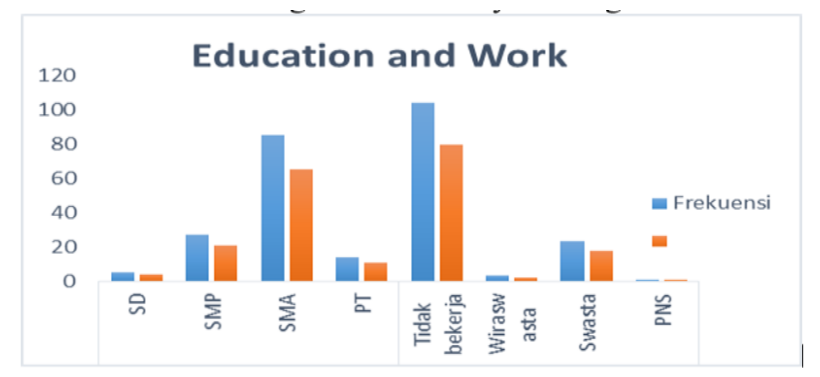

Figure 2 shows that the highest value is found in respondents who have high school education and do not work (SMA and Tidak Bekerja). Meanwhile, education with (SD) elementary school qualification and working as a civil servant (PNS) is the lowest.

Table 1.The relationship between predisposing, enabling, reinforcing factors and def-t.

\begin{tabular}{lcccccccccccc}
\hline Variable & Mean \pm SD & \multicolumn{2}{c}{ Behavior } & \multicolumn{2}{c}{ Predisposing } & \multicolumn{2}{c}{ Enabling } & \multicolumn{2}{c}{ Reenforcing } & \multicolumn{2}{c}{ def-t } \\
& & $\mathrm{R}$ & $\mathrm{p}$ & $\mathrm{R}$ & $\mathrm{p}$ & $\mathrm{R}$ & $\mathrm{p}$ & $\mathrm{R}$ & $\mathrm{p}$ & $\mathrm{R}$ & $\mathrm{p}$ \\
\hline Behavior & $163.17 \pm 13.407$ & & & 0.96 & 0 & 0.68 & 0 & 0.76 & 0 & -0.79 & 0 \\
Predisposing & $107.90 \pm 9.509$ & 0.96 & 0 & & & 0.55 & 0 & 0.68 & 0 & -0.73 & 0 \\
Enabling & $36.06 \pm 3.495$ & 0.68 & 0 & 0.55 & 0 & & & 0.52 & 0 & -0.51 & 0
\end{tabular}




\begin{tabular}{|c|c|c|c|c|c|c|c|c|c|c|}
\hline Reinforcing & $19.21 \pm 1.912$ & 0.76 & 0 & 0.68 & 0 & 0.52 & 0 & & & $-0.56 \quad 0$ \\
\hline def-t & $9,06 \pm 4,877$ & -0.8 & 0 & -0.73 & 0 & -0.51 & 0 & -560 & 0 & \\
\hline
\end{tabular}

Table 1 shows, the correlation analysis between behavioral factors, indicated by indicators, predisposing, enabling, reinforcing, and caries severity or def-t, shows a significant relationship with $\mathrm{p}=0.000>0.005$.

\section{Implementation of Empowerment}

Training and Empowerment of cadres/mothers about the prevention and management of dental disease or Cegah dan Tangani Penyakit Gigi (Cegatan Pagi). The results obtained from the assessment checklist; cadres were able to convey information using learning media in accordance with the predetermined point stages. After that, a post-test was carried out consisting of 10 questions with multiple choice answers.

Table 2. Significance value of pretest and post test

\begin{tabular}{lcc}
\hline Variable & Mean \pm SD & Sig (2-tailed) \\
\hline Pre-test & $5,20 \pm 1.424$ & 0,000 \\
Post-test & $8.33 \pm 1.291$ & \\
\hline
\end{tabular}

In Table 2. the mean \pm SD pre-test value is 5,20 \pm 1.424 and the mean \pm SD post-test value is $8.33 \pm 1.291$. The post-test score has a higher mean than the pre-test means with a difference of 3.13. To find out whether there was a difference before (pre-test) and after (posttest) the intervention, a paired sample t-test was analyzed. The results of the paired sample ttest showed a result of 0.022 ( $\mathrm{p}<0.05)$ so that the results showed that there was an effect of the pre $\&$ post variable treatment.

Providing education through the Snake and Ladder Educational Game on Children's Oral and Dental Health or Bermain Ular Tangga Kesehatan Gigi Dan Mulut (Beruang Imut). The results evaluation was carried out when the first program was completed, which aimed to measure whether there was an increase in maternal knowledge regarding the prevention, treatment, and detection of dental caries in children after being given the first intervention, then given the second program intervention, through the game of snakes and ladders. This increase in knowledge can be seen from the results of the pre-test and post-test.

Table 3. Significance value of pretest and post test

\begin{tabular}{lcr}
\hline & Rata-Rata & Sig (2-tailed) \\
\hline Pre-test & $8,33 \pm 1.291$ & 0,022 \\
\hline Post-test & $9,20 \pm .676$ & \\
\hline
\end{tabular}

In Table 3. the mean \pm SD pre-test value is $8.33 \pm 1.291$ and the mean \pm SD post-test value is $9.20 \pm 0.676$. The post-test score has a higher mean than the pre-test with a difference of 0.87 . To find out whether there was a difference before (pre-test) and after (post-test) the intervention, a paired sample t-test was analyzed. The results of the paired sample t-test showed a result of $0.022(\mathrm{p}<0.05)$ so that the results showed that there was an effect of the pre $\&$ post variable treatment. 

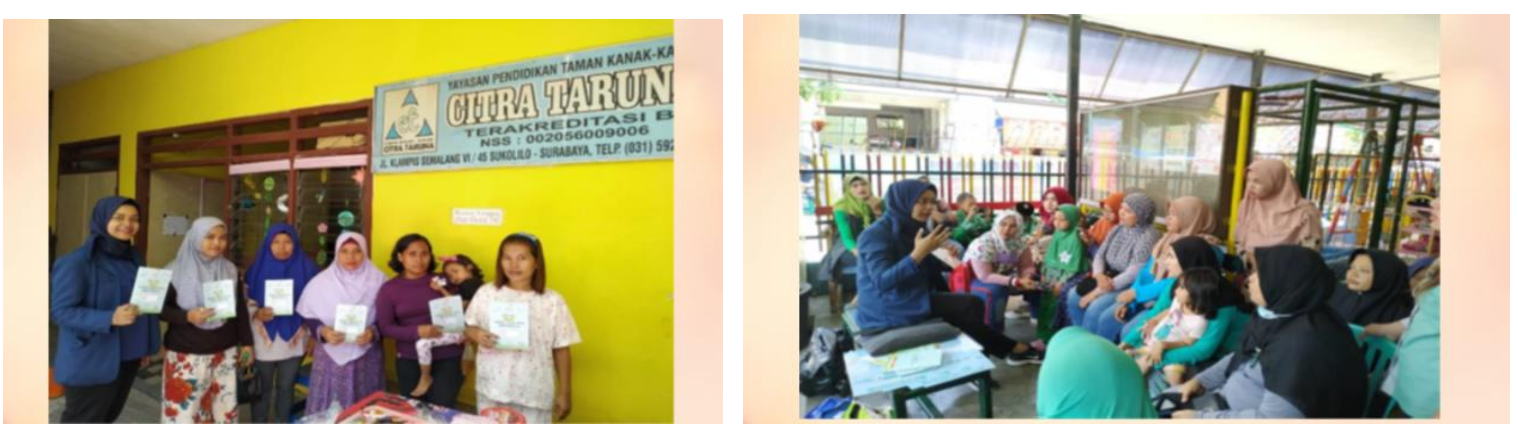

Figure 3.and 4 Training and Empowerment of cadres/mothers about the prevention and management of dental disease or Cegah dan Tangani Penyakit Gigi (Cegatan Pagi).
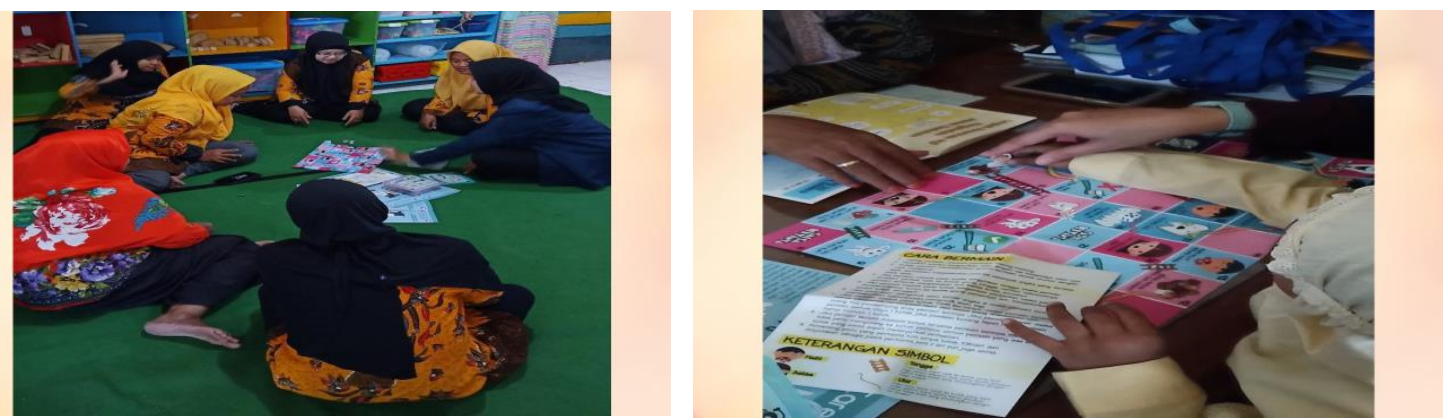

Figure 5 and 6 Self-study through Snakes and Ladders game (Permainan Ular tangga)

\section{Discussion}

Parents are considered to have the knowledge to teach their children basic things about maintaining a healthy body. The cultivation of dental and oral health behaviors should start at an early age and start from the family environment. Childhood is the beginning of behavior formation; therefore, parents are expected to be able to educate their children to behave properly to maintain healthy teeth and mouth. Knowledge of children's dental health is a must for a mother for the development and growth of good children's teeth. The knowledge and ability of parents in maintaining children's dental health can be influenced by several things, including age, education, socio-economic status, experience, information on mass media and the environment (I Komang Evan Wijaksana dkk 2020).

The knowledge of the mother who is the closest person to the child in health care has a significant influence on the child's attitudes and behavior. Kindergarten-age children generally do not know and are not able to maintain the health of their oral cavity, so parents are responsible for educating them properly. ${ }^{6}$ In this school, children usually like to eat and drink snacks according to their wishes. Caries disease in children is common and often occurs but does not get the attention of parents on the assumption that children's teeth will be replaced by permanent teeth.

Media or props are tools used by educators to help and explain something in the educational or teaching process. Useful media generate target interest, stimulate targets to forward messages to others, and facilitate the delivery of information. Children are easily bored so that to encourage children to learn, usually teachers and parents tend to use various teaching aids and games to provoke children's interest in learning. ${ }^{11}$ For effective learning, it is not enough just to provide information, but it is necessary to give these students experience. $^{12}$

Research conducted by Hamdalah, the game of snake and ladder media is more effective increase knowledge and attitudes towards oral health and the practice of brushing teeth. properly and correctly. ${ }^{13}$ The increase in knowledge, attitudes, and practices towards 
oral health was higher in the group that received counseling with the snake and ladder game media than the pictorial story media group.

Based on epidemiological research conducted on kindergarten students in Surabaya, it was found that there was a significant relationship between the number of DMF-T and children's knowledge. This research has proven that the knowledge of children's teeth and mouth is mostly in the bad category. And based on the analysis of the results, it is known that children with higher caries tend to have poor knowledge of dental and oral health. To increase children's knowledge, one of them is empowerment with the aim of improving children's knowledge. In this empowerment method is applied indirectly, namely by utilizing game media that can stimulate children's psychomotor so that it makes it easier for children to receive information about oral health because it is done by using the playing and learning method.

Education about oral health is an important component in health promotion and includes health services. The purpose of this health promotion is to provide information to raise awareness and then lead to the implementation of good behavior. ${ }^{12}$ Selection of the snake and ladder educational game media "PLAYING THE SNAKE LADDER AND MOUTH HEALTH aims to make children interested and easier to get information with assistance. by the teacher as an information mediator. With games that involve sensorimotor, children will recognize soft, smooth, rough, or rigid surfaces, thereby increasing their ability to abstraction (imagination, fantasy). Through play, children will also get more information so that their knowledge and understanding is richer and deeper. If this new information turns out to be different from what he already knows, the child gets new knowledge. When playing, children must pay attention to the perspective of their opponents playing, thereby reducing their egocentricity. In this game, children can also know how to compete honestly, be fair, know their rights and care about the rights of others. Children can also learn how to be a team and team spirit as well as the right way to communicate. Hopefully through these games children can know the importance of maintaining oral health. And the school can also continue to facilitate the oral education learning program.

\section{Conclusion}

Training and empowerment of cadres / mothers regarding the prevention and handling of dental diseases or Preventing and Managing Dental Diseases, as well as providing education through Snakes and Ladders Educational Games on Children's Oral and Dental Health or Playing Snakes and Ladders for Dental and Oral Health, can overcome the difficulties of mothers in educating their children about oral health. This snake and ladder game is expected to increase children's understanding and interest in maintaining oral health. Media is useful for arousing target interest, stimulating targets to forward messages to others, and facilitating the delivery of information. The caries severity factor for children aged 4-6 years is estimated to decrease.

\section{Suggestion}

This empowerment program is applied to preschool children through the cadres that have been formed.

\section{Acknowledgments}

We would like to thank and show our gratitude to Airlangga University for providing funding support for this service (Universitas Airlangga Community Development Program Number Nomor 532 /UN3/2020) 


\section{Reference}

Ahmed, T. E. S. dan Abuaffan, A. H. 2015. Correlation between Body Mass Index and Dental Caries among A Sample of Sundanese Children. (December). 18 (3):42

Bankole, F.O. Bankole, O. and Brown I. 2011. "Mobile Banking Adoption in Nigeria," The Electronic Journal on Information Systems in Developing Countries. 47( 2): pp. 2-7,

I Komang Evan Wijaksana, Lambang Bargowo, Shafira Kurnia Supandi, 2020, "Periodontal Health Improvement on Pregnancy to Reduce Low-Birth-Weight Infants Risk", Jurnal Layanan Masyarakat (Journal of Public Service).vol 4 (2) :p.275-281

Indry W, Christy NM, Paulina G. 2013. "Pengalaman Karies Gigi Serta Pola Makan Dan Minum Pada Anak Sekolah Dasar di Desa Kiawa Kecamatan Kawangkoan Utara". Manado. Jurnal e-GiGi. 1(1): hlm. 59-68

King N. 1 M, Anthonappa R. P, Itthagarun A.t, 2007 The importance of the primary dentition to children - Part 1: Consequences of not treating carious teeth. 29(2): 52-61

Munifah Abdat*, Ivan Ramayana. 2020 "Relationship between mother's knowledge and behaviour with oral health status of early childhood". Padjadjaran Journal of Dentistry. 32(3) p:166-173.

National of Dental and Craniofacial Research, 2018. Advancing the nation's Oral Health through research and innovation, National institute of Dental and craniofacial research.1-14

Pitts, N. B., Zero, D. T., Marsh, P. D., Ekstrand, K., Weintraub, J. A., Ramos-Gomez, F., Ismail, A. 2017. Dental Caries. Nature reviews Disease primers. 3 : 17030.

Riset Kesehatan Dasar. 2018. Badan Penelitian dan Pengembangan Kesehatan Kementerian RI. http://www.depkes.go.id-Diakses Agustus

Shabiralyani1 G, Shahzad Hasan K., Hamad N., Iqbal N. 2015 "Impact of Visual Aids in Enhancing the Learning Process CaseResearch: District Dera Ghazi Khan". Journal of Education and Practice. 6(19):226

Wang D.*, van der Horst K., Jacquier E.F.,. Afeiche M. C and Alison L. 2018 Eldridge Snacking Patterns in Children: A Comparison between Australia, China, Mexico, and the US, Nutrients, 10(2):198;1-14.

World Health Organization (WHO). 2012. Karies pada anak. Amerika: WHO. 